\title{
Contribution of a herb and clover mix to spring and autumn sown forage for dryland dairying
}

\author{
J.L. JACOBS, G.N. WARD, P. MASKELL and F.R. MCKENZIE \\ Primary Industries Research Victoria, Department of Primary Industries, Warrnambool, Vic 3280 \\ joe.jacobs@dpi.vic.gov.au
}

\begin{abstract}
This study investigated companion crops and time of sowing of a herb (chicory and plantain) and clover (red and white clover) mix in dairy pasture systems. Five summer crops (turnip, rape, turnip-rape, radish and millet), sown alone or in combination with herb/clover in spring 2003, were compared over the first summer. Dry matter (DM) production was higher for millet and rape than turnip-rape or radish. Metabolisable energy (ME) content of millet and turnip was lower, and neutral detergent fibre (NDF) content of millet higher than all other crops. Inclusion of herb/clover reduced ME and increased NDF at the second grazing. In autumn 2004, an Italian ryegrass + herb/clover mix was direct drilled into plots without the spring sown herb/clover mix, and Italian ryegrass only into the remaining plots. The spring sown herb/clover system resulted in higher herbage DM at the first grazing (June 2004) after sowing Italian ryegrass, but lower production in spring 2004 than the autumn sown herb/clover system. There were no differences in DM production at any other grazings. In winter and spring 2004, ME was higher for autumn than for spring sown herb/clover. Crude protein content was higher for autumn sown herb/clover in June and July than for spring sown, but lower from December 2004 to April 2005. From September 2004 to August 2005, the NDF content of spring sown herb/clover was lower than for autumn sown. Throughout the study, both chicory and plantain content $(\% \mathrm{DM})$ was higher and weed and dead matter lower, with spring compared to autumn sowing.
\end{abstract}

Keywords: herbage production, chicory, plantain, metabolisable energy, weed suppression

\section{Introduction}

Perennial ryegrass (Lolium perenne L.) and white clover (Trifolium repens L.) are the primary species sown in dryland dairy pastures in southern Victoria due to their potential for high annual dry matter (DM) production and nutritive value (Doyle et al. 2000). However, this annual supply of herbage DM is uneven with up to $70 \%$ produced during spring (Jacobs et al. 1999). Summer crops form an integral component of forage based systems in southern Victoria as they have the ability to produce large quantities of forage with a high nutritive value when perennial pastures have low growth rates
(Notman 1994). Despite these potential benefits to growing summer forage crops, DM yields can vary considerably with Jacobs et al. (2001) observing a range in turnip DM yields of 0.4 to $19.2 \mathrm{t} \mathrm{DM} / \mathrm{ha}$ and an average of $5 \mathrm{tDM} /$ ha in south west Victoria. Furthermore, in early autumn, resowing following summer crops is required which may result in land not producing adequate DM for grazing until late winter. The incorporation of perennial herbs such as chicory (Cichorium intybus L.) and plantain (Plantago lanceolata L.) may offer greater flexibility in the supply of feed through the year, particularly in summer and autumn. It is well established that these species have drought tolerance (Jung et al. 1996; Stewart 1996) and provide feed of high nutritive value (Stewart 1996; Barry 1998). Whilst data indicate the growth potential for chicory (Li et al. 1997) and plantain (Stewart 1996) over late spring, summer and autumn their use in southern Victoria has been limited, with little data available to determine their potential in mixed swards. The aim of this study was to determine the value of integrating a herb/clover mix into dryland dairy pasture systems in terms of their contribution to forage DM production, their influence on nutritive characteristics and the best time for establishment in such an environment.

\section{Materials and methods \\ Site and design}

This trial was conducted on a commercial dairy farm (38 $14^{\prime}$ S; $142^{\circ} 55^{\prime}$ E) in south west Victoria. The soil was a brown chromosol and initial tests (September $2003)(0-10 \mathrm{~cm})$ indicated good levels of fertility with a $\mathrm{pH}_{\mathrm{H} 2 \mathrm{O}}$ of 5.5 , Olsen P of $26 \mathrm{mg} / \mathrm{kg}$, Skene K of 210 $\mathrm{mg} / \mathrm{kg}$ and CPC S of $13 \mathrm{mg} / \mathrm{kg}$.

On 28 September 2003, the experimental area was sprayed with Roundup Max at $3 \mathrm{~L} / \mathrm{ha}(540 \mathrm{~g} / \mathrm{L}$ glyphosate), Dicamba $500 \mathrm{ml} / \mathrm{ha}(500 \mathrm{~g} / \mathrm{L}$ dicamba) and Le-Mat $100 \mathrm{ml} / \mathrm{ha}(290 \mathrm{~g} / \mathrm{L}$ omethoate) and grazed 10 days later. On 16 October the area was mouldboard ploughed and on 23 October power harrowed. Treatment plots $(50 \mathrm{~m} \times 30 \mathrm{~m})$ were sown with turnip (Brassica rapa L. cv. Rival), turnip-rape (Brassica campestris L. x Brassica napus L. cv. Hunter), rape (Brassica napus L. cv. Winfred), radish (a complex hybrid of Raphanus sativus L. cv. Graza) or millet (Echinochloa utilis Ohwi \& Yabuno cv. Shirohie). Each crop was sown alone 
(turnip, $2 \mathrm{~kg} / \mathrm{ha}$; turnip-rape, $4 \mathrm{~kg} / \mathrm{ha}$; rape, $3 \mathrm{~kg} / \mathrm{ha}$; radish, $10 \mathrm{~kg} / \mathrm{ha}$; millet, $15 \mathrm{~kg} / \mathrm{ha}$ ) or each was sown in combination (turnip, $1.5 \mathrm{~kg} / \mathrm{ha}$; turnip-rape, $3 \mathrm{~kg} / \mathrm{ha}$; rape, $2 \mathrm{~kg} / \mathrm{ha}$; radish, $8 \mathrm{~kg} / \mathrm{ha}$; millet, $10 \mathrm{~kg} / \mathrm{ha}$ ) with chicory (cv. Grouse) $(2 \mathrm{~kg} / \mathrm{ha})$, plantain (cv. Tonic) $(3 \mathrm{~kg} / \mathrm{ha})$, white clover (cvs. Nusiral, Prestige) $(2 \mathrm{~kg} / \mathrm{ha})$ and red clover (Trifolium pratense L. cv. Colenso) $(2 \mathrm{~kg} / \mathrm{ha})$ (termed herb/clover). All treatments were replicated four times in a randomised block design. At sowing, triple superphosphate was applied at $100 \mathrm{~kg} / \mathrm{ha}(20.2 \mathrm{~kg} \mathrm{P}, 1.0$ $\mathrm{kg} \mathrm{S} / \mathrm{ha})$ with $120 \mathrm{~kg} / \mathrm{ha}$ muriate of potash $(60 \mathrm{~kg} \mathrm{~K} / \mathrm{ha})$ being surface applied 3 days later. Over summer, all treatments were grazed twice, with grazing based on the maturity of the summer crop in respective plots. On 26 April 2004, all plots were direct drilled using a triple disc machine with Italian ryegrass (Lolium multiflorum Lam. cv. Crusader) $(20 \mathrm{~kg} / \mathrm{ha})$ and the herb/clover mix was included in plots where they were not sown in the previous spring. No cultivation or herbicide was applied prior to direct drilling the plots. All plots also received $500 \mathrm{~kg} / \mathrm{ha} 3 \& 1$ super potash $(33 \mathrm{~kg} \mathrm{P}, 63.5 \mathrm{~kg} \mathrm{~K}, 41 \mathrm{~kg}$ $\mathrm{S} / \mathrm{ha}$ ) on 14 April 2004 and $500 \mathrm{~kg} / \mathrm{ha} 4 \& 1$ super potash (35 kg P, $50 \mathrm{~kg} \mathrm{~K}, 44 \mathrm{~kg} \mathrm{~S} / \mathrm{ha}$ ) on 29 April 2005. Nitrogen fertiliser $(50 \mathrm{~kg} \mathrm{~N} / \mathrm{ha}$ as urea) was applied on 19 December 2003, 3 May 2004, 9 August 2004, 14 October 2004, 8 June 2005, 15 July 2005 and 24 August 2005. Plots were block grazed with the milking herd for $8-24$ hours per grazing. During autumn, winter and early spring, all plots were grazed when the ryegrass (in the vegetative stage of growth) reached the 3-leaf stage of development. During late spring and summer, the 3-leaf stage was not deemed appropriate and all plots were grazed when the most advanced treatments attained a pre grazing mass of 2100-2300 kg DM/ha.

\section{Measurements}

Pre-grazing herbage measurements were taken 1 day prior to grazing and post grazing measurements within 2 days after grazing. Herbage DM production and DM residual were estimated before and after grazing by cutting $10,1 \mathrm{~m}^{2}$ quadrats per plot. Quadrat samples were weighed individually and sub sampled on a plot basis. Resultant sub samples were weighed, dried at $100^{\circ} \mathrm{C}$ to constant weight, and DM accumulation calculated. Prior to each grazing, 30 randomly cut herbage samples $(5 \mathrm{~cm}$ x $15 \mathrm{~cm}$ quadrat cut to ground level) per plot were collected. Samples were thoroughly mixed with a sub sample taken to determine botanical composition (\%DM), which was hand sorted into different components (summer crop, chicory, plantain, ryegrass, red clover, white clover, weeds and dead material). Sorted samples were oven dried at $100^{\circ} \mathrm{C}$ for $24 \mathrm{~h}$, weighed and used to calculate the proportion of each component within the sward. A further sub sample was washed and dried at $60^{\circ} \mathrm{C}$ for $72 \mathrm{~h}$, ground through a 1 $\mathrm{mm}$ screen and used for chemical analyses. Ground herbage samples were analysed by FEEDTEST, Primary Industries Research Victoria, Hamilton for crude protein (CP) (nitrogen concentration x 6.25), neutral detergent fibre (NDF) and dry matter digestibility (DMD). Metabolisable energy (ME) (MJ/ $\mathrm{kg} \mathrm{DM}$ ) values were calculated from predicted DMD values using the formula:

$$
\mathrm{ME}=\{0.164(\mathrm{DMD} \%+\mathrm{EE})-1.61\},
$$

where $\mathrm{EE}=$ Ether Extract $(\%$ of DM) but assumed to be $2 \%$ for all types of fodder (AFIA 2002).

\section{Statistical analyses}

To model the repeated measurements, all data were analysed using restricted maximum likelihood (REML) in which the correlation between observations from the same plot decays as the time delay between the observations increases. Significance was declared if $\mathrm{P}<0.05$. All statistical analyses were performed using GenStat (GenStat Committee 2003). Data are presented as two periods, the first being the initial summer (2004) with comparisons between summer crops sown with and without the herb/clover mix. The second period is from autumn 2004 where effects of spring and autumn sown herb/clover are compared.

\section{Results}

\section{Period 1}

Total DM accumulation was higher $(\mathrm{P}<0.05)$ for millet and rape than turnip-rape or radish (Table 1) with the majority of DM accumulation occurring at the first grazing. Over the first summer, the ME content of millet and turnip was lower $(\mathrm{P}<0.05)$ and NDF content of millet higher $(\mathrm{P}<0.05)$ than other crops. By the second grazing, the inclusion of herb/clover resulted in lower $(\mathrm{P}<0.05) \mathrm{ME}$, and higher $(\mathrm{P}<0.05) \mathrm{NDF}$ contents compared to the crop only treatments. There were no interactions between summer crop and herb/clover.

\section{Period 2}

The spring sown herb/clover system resulted in higher $(\mathrm{P}<0.05)$ herbage DM accumulation at the first grazing (June 2004), but lower $(\mathrm{P}<0.05)$ production in the first spring (October, November 2004) than for autumn sown herb/clover (Table 2). There were no differences in DM production at any other grazing with total DM accumulation for the period (April 2004 - October 2005) being similar for the two sowing times (spring, 19.62; autumn, $19.11 \mathrm{t} \mathrm{DM/ha).} \mathrm{In} \mathrm{the} \mathrm{first} \mathrm{winter} \mathrm{(July}$ 2004) and spring (September, October 2004), ME content for autumn sown herb/clovers was higher $(\mathrm{P}<0.05)$ than for spring sown. Crude protein content was higher $(\mathrm{P}<0.05)$ for autumn sown herb/clover in 
Table 1 The effect of different summer crops with and without herb/clover on herbage DM accumulation (t DM/ ha), metabolisable energy (MJ/kg DM) (ME), crude protein (\%DM) (CP) and neutral detergent fibre (\%DM) (NDF) over the first two grazing periods in summer (G1 and G2).

\begin{tabular}{|c|c|c|c|c|c|c|c|c|c|}
\hline & \multicolumn{2}{|c|}{ DM } & \multirow[t]{2}{*}{ Total DM } & \multicolumn{2}{|c|}{$\mathrm{ME}$} & \multicolumn{2}{|c|}{$\mathrm{CP}$} & \multicolumn{2}{|c|}{ NDF } \\
\hline & G1 & G2 & & G1 & G2 & G1 & G2 & G1 & G2 \\
\hline \multicolumn{10}{|l|}{ Summer crop } \\
\hline Turnip-rape & 3.35 & 1.52 & 4.87 & 13.2 & 12.0 & 13.8 & 13.6 & 23.4 & 24.5 \\
\hline Millet & 4.74 & 1.89 & 6.63 & 10.1 & 10.3 & 11.8 & 16.2 & 57.8 & 50.8 \\
\hline Radish & 3.03 & 1.90 & 4.93 & 13.0 & 12.3 & 14.1 & 15.7 & 25.2 & 26.5 \\
\hline Turnip & 5.15 & 0.62 & 5.77 & 11.4 & 10.2 & 16.4 & 18.0 & 30.9 & 34.7 \\
\hline Rape & 4.96 & 1.63 & 6.59 & 13.7 & 11.8 & 12.7 & 19.5 & 22.0 & 25.8 \\
\hline${ }^{*} \operatorname{LSD}(\mathrm{P}=0.05)$ & \multicolumn{2}{|c|}{0.535} & 1.067 & \multicolumn{2}{|c|}{0.59} & \multicolumn{2}{|c|}{1.88} & \multicolumn{2}{|c|}{2.99} \\
\hline \multicolumn{10}{|l|}{ Herb/clover } \\
\hline+ & 4.08 & 1.42 & 5.50 & 12.3 & 10.7 & 13.5 & 17.0 & 31.9 & 34.6 \\
\hline- & 4.41 & 1.61 & 6.02 & 12.3 & 11.9 & 14.1 & 16.2 & 31.8 & 30.3 \\
\hline${ }^{*} \operatorname{LSD}(\mathrm{P}=0.05)$ & \multicolumn{2}{|c|}{0.339} & 0.676 & \multicolumn{2}{|c|}{0.37} & \multicolumn{2}{|c|}{1.20} & \multicolumn{2}{|c|}{1.89} \\
\hline
\end{tabular}

* The REML generated LSD applies to both grazing times (G1 and G2)

Table 2 The effect of spring (S) or autumn (A) sown herb/clover on herbage DM accumulation (t DM/ha), metabolisable energy (MJ/kg DM) (ME), crude protein (\%DM) (CP) and neutral detergent fibre (\%DM) (NDF) of an autumn sown Italian ryegrass based pasture at each grazing.

\begin{tabular}{|c|c|c|c|c|c|c|c|c|}
\hline & \multicolumn{2}{|c|}{ DM } & \multicolumn{2}{|c|}{ ME } & \multicolumn{2}{|c|}{$\mathrm{CP}$} & \multicolumn{2}{|c|}{ NDF } \\
\hline & $S$ & $A$ & $\mathrm{~S}$ & $A$ & $\mathrm{~S}$ & $A$ & S & $A$ \\
\hline 20 Jun 2004 & 2.18 & 1.54 & 11.2 & 11.6 & 26.5 & 31.0 & 34.4 & 35.3 \\
\hline 27 Jul & 1.21 & 1.00 & 11.5 & 11.9 & 21.3 & 23.3 & 34.6 & 35.3 \\
\hline 9 Sep & 1.26 & 1.58 & 11.9 & 11.8 & 19.3 & 19.9 & 35.8 & 40.0 \\
\hline 12 Oct & 1.57 & 2.06 & 10.7 & 11.2 & 16.7 & 16.5 & 43.9 & 47.0 \\
\hline 11 Nov & 1.75 & 2.17 & 9.6 & 10.2 & 18.8 & 18.0 & 50.8 & 53.1 \\
\hline $6 \mathrm{Dec}$ & 2.10 & 1.83 & 10.6 & 10.4 & 17.4 & 15.3 & 47.5 & 53.5 \\
\hline 2 Jan 2005 & 1.87 & 1.80 & 9.2 & 9.2 & 13.6 & 11.8 & 53.3 & 58.2 \\
\hline 23 Feb & 1.00 & 0.72 & 9.3 & 9.2 & 13.2 & 11.9 & 52.5 & 58.2 \\
\hline $11 \mathrm{Apr}$ & 0.51 & 0.51 & 9.1 & 8.9 & 12.1 & 9.9 & 55.0 & 61.4 \\
\hline 10 Jul & 0.52 & 0.48 & 10.2 & 10.5 & 27.4 & 26.4 & 46.2 & 48.1 \\
\hline 7 Aug & 1.00 & 1.08 & 11.1 & 11.2 & 29.9 & 29.1 & 46.5 & 49.1 \\
\hline 7 Sep & 1.60 & 1.45 & 11.2 & 11.3 & 29.0 & 28.1 & 46.6 & 48.2 \\
\hline 29 Sep & 1.48 & 1.50 & 11.5 & 11.4 & 24.5 & 24.0 & 45.7 & 47.8 \\
\hline 26 Oct & 1.57 & 1.39 & 10.4 & 10.4 & 22.2 & 22.2 & 51.7 & 52.9 \\
\hline${ }^{*} \operatorname{LSD}(\mathrm{P}=0.05)$ & \multicolumn{2}{|c|}{0.339} & \multicolumn{2}{|c|}{0.37} & \multicolumn{2}{|c|}{1.20} & \multicolumn{2}{|c|}{1.89} \\
\hline
\end{tabular}

* The REML generated LSD applies to both seasons at each grazing

autumn (June) and winter (July) of 2004 than for spring sown, whilst the opposite occurred from December 2004 to April 2005. From September 2004 to August 2005 the NDF content of spring sown herb/clover was lower $(\mathrm{P}<0.05)$ than for autumn sown.

On average over all assessments, spring sown herb/ clover resulted in greater proportions (\%DM) of both herbs (chicory 13\%; plantain 18\%) and red but not white clover (white clover, 2\%; red clover, $2 \%$ ) and lower proportions of Italian ryegrass (41\%), weeds (4\%) and dead matter ( $9 \%$ ) than autumn sown herb/clovers (chicory, 1\%; plantain, 2\%; white clover, $2 \%$; red clover, $0 \%$; Italian ryegrass, 58\%; weed, 8\%; dead, 11\%) (Fig. $1)$. During autumn, winter and early spring of 2004, the weed content was lower $(\mathrm{P}<0.05)$ where herb/clover had been spring sown (range 4 to $8 \%$ ), compared with autumn sown (range $17-25 \%$ ).

\section{Discussion}

Dry matter production ranges from summer crops, were within ranges observed from other studies in a similar environment (Jacobs et al. 2001, 2004). Spring sowing of the herb/clover mix led to additional DM production in late autumn of Year 1 compared to autumn sowing of these species. This increase was primarily due to DM production from chicory and plantain which constituted close to $70 \%$ of the sward at this time. Whilst there was a steady decline in the contribution from chicory and plantain during winter and spring in Year 1, the weed component remained less than $10 \%$ until late spring. This suggests that spring sowing of these herbs provided adequate ground cover to reduce weed invasion in the following autumn prior to establishment of the ryegrass. This study was sown with Italian ryegrass in autumn, whereas if slower establishing perennial ryegrass had 
Figure 1 Botanical composition (mean for all crops) of (A) summer forage crops established in spring with a herb/clover mix and subsequently direct drilled with Italian ryegrass in autumn; and (B) summer forage crops established in spring and direct drilled with Italian ryegrass and herb/clover mix in autumn. Light shading, summer crop; white, chicory; spotted, dead; black, plantain; horizontal stripes, Italian ryegrass; dark shading, clover; angled striping, weeds.
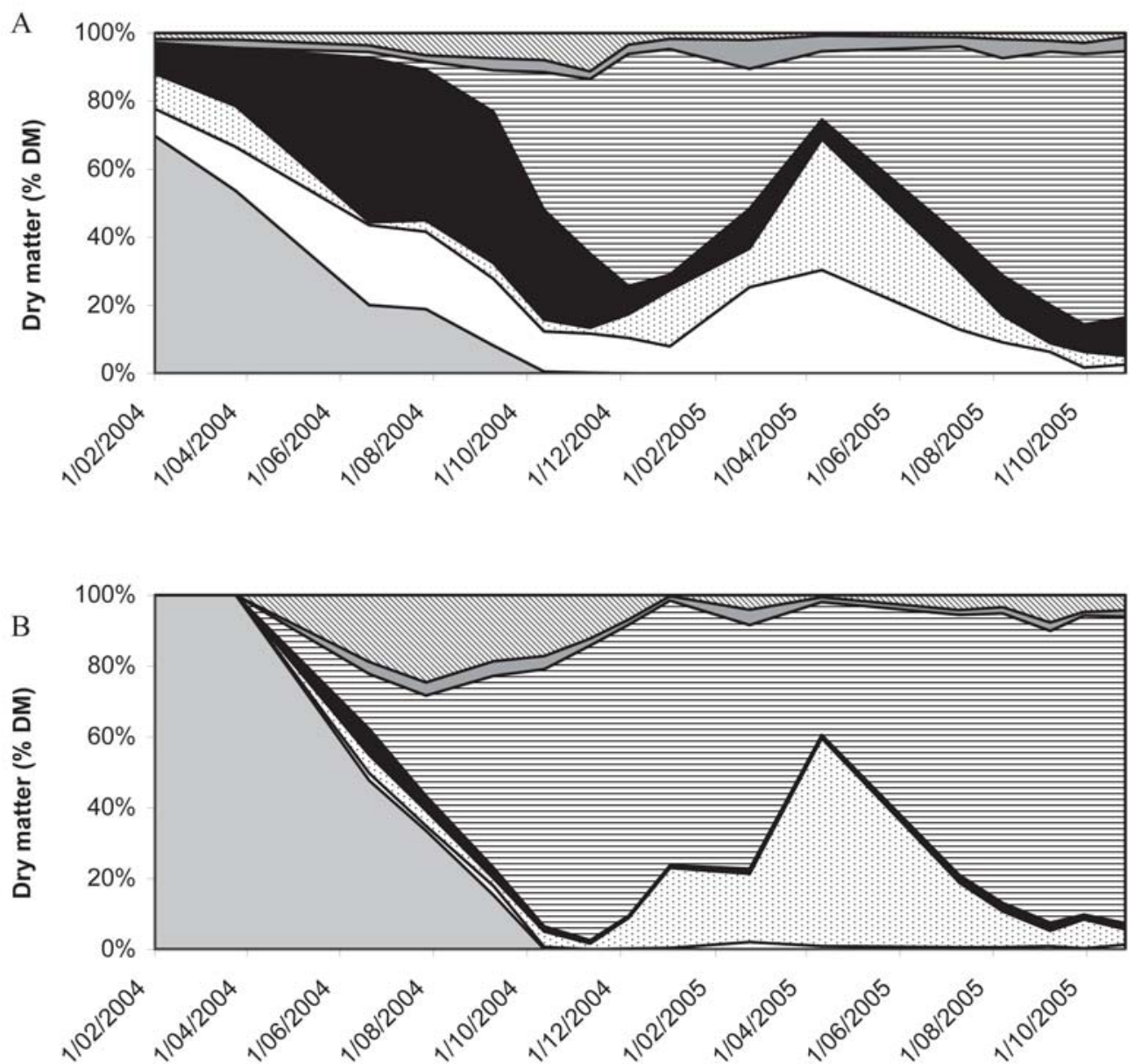

been used, it is likely that the DM contribution from herb/clover would have been greater with less competition from the ryegrass. Whilst the proportion of chicory and plantain in the spring sown treatment declined to less than $15 \%$ of available DM a year after sowing (late spring 2004), it increased to $35 \%$ by autumn in Year 2, thus still contributing to the total DM production of the sward. The lower ME values observed for the spring sown herb/clover in September and October 2004 are likely to be a result of both chicory and plantain entering their reproductive phase (Stewart 1996; Barry 1998). Given that grazing rotation was based on the ryegrass component of the sward reaching particular targets, this may have led to a rotation interval that precluded adequate control of chicory and plantain reproductive development. Li et al. (1997) comment that a grazing interval of approximately 3 weeks is required to restrict reproductive development in chicory and grazing intervals of greater than 5 weeks gave poorer control. In the current study, grazing intervals in late spring and summer ranged from 4 to 8 weeks. However, despite potential issues with grazing management, the $\mathrm{CP}$ content over summer 2005 was higher, and NDF was lower where herb/clover made up a greater proportion of the sward indicating that such mixes give greater flexibility in the choice of complementary feeds offered.

This study demonstrated that herbs sown with summer forage crops in spring can increase forage production during the following autumn and reduce weed ingression into newly sown pastures during the first year. When high chicory contents are achieved, maintaining nutritive value during late spring and summer may require more frequent grazing than normally used for ryegrass based pastures. 


\section{ACKNOWLEDGEMENTS}

The authors wish to acknowledge the financial contributions of WestVic Dairy, Pyne Gould Guinness, Stephen Pasture Seeds and DemoDAIRY.

\section{REFERENCES}

AFIA 2002. Laboratory Methods Manual. Australian Fodder Industry Association, Melbourne, Australia.

Barry, T.N. 1998. The feeding value of chicory (Cichorium intybus) for ruminant livestock. Journal of Agricultural Science, Cambridge 131: 251-257.

Doyle, P.T.; Stockdale, C.R.; Lawson, A.R.; Cohen, D.C. 2000. Pastures for Dairy Production in Victoria. Rodney Printers, Tatura, Victoria.

GenStat Committee 2003. 'GenStat ${ }^{\circledR}$ Release 7.1.'(VSN International Ltd: Oxford.)

Jacobs, J.L.; McKenzie, F.R.; Ward, G.N. 1999. Changes in the botanical composition and nutritive characteristics of pasture, and nutrient selection by dairy cows grazing rainfed pastures in western Victoria. Australian Journal of Experimental Agriculture 39: 419-28.

Jacobs, J.L.; Ward. G.N.; McDowell, A.M.; Kearney, G. 2001. A survey on the effect of establishment techniques, crop management, moisture availability and soil type on turnip dry matter yields and nutritive characteristics in western Victoria. Australian Journal of Experimental Agriculture 41, 743-751.

Jacobs, J.L.; Ward. G.N.; McKenzie, F.M. 2004. Effect of irrigation strategies on dry matter yields and water use efficiency of a range of forage species. Pp 142. In: Proceedings of the 4th International Crop Science Congress, Brisbane, Australia.

Jung, G.A.; Shaffer, J.A.; Varga, G.A.; Everhart, J.R. 1996. Performance of 'Grasslands Puna' Chicory at different management levels. Agronomy Journal 88: 104-111.

Li, G.D.; Kemp, P.D.; Hodgson, J. 1997. Herbage production and persistence of Puna Chicory (Cichorium intybus L.) under grazing management over 4 years. New Zealand Journal of Agricultural Research 40: 51-56.

Notman, P. 1994. Turnips - a farmer's experience. pp 60-69. In: Proceedings of the Grassland Society of Victoria 35th Annual Conference. (Grasslands Society of Victoria: Parkville, Vic.)

Stewart, A.V. 1996. Plantain (Plantago lanceolata) - a potential pasture species. Proceedings of the New Zealand Grassland Association 58: 77-86. 